\title{
Mannheim-Heidelberg 2003
}

\author{
By Gönül Dönmez-Colin
}

Spring 2004 Issue of KINEMA

\section{MANNHEIM-HEIDELBERG INTERNATIONAL FILM FESTIVAL 2003}

One of the oldest festivals of Germany, Mannheim-Heidelberg International Film Festival has remained loyal to its motto of 'new comers' festival' showcasing films from unknown talents or totally marginalized filmmakers who favour exploring new film language. This year's event, which took place from 20 to 29 November, 2003 presented a large selection of films from Europe such as De Arm van Jezus (The Arm of Jesus) by Andre van der Hout from Holland, Sauja lozu (Handful of Bullets) by Una Celma from Latvia, Baby by Linda Wendel from Denmark and Donau, Dunaj, Duna, Dunav, Dunarea by Goran Rebi from Austria.

From Iran, an eye-catching film was Khamoushiye Darya (The Silence of the Sea) by Vahid Mousaian, a visual reflection on exile's return tracing the tormented journey of an Iranian doctor settled in Sweden as he smuggled himself into his country of birth sans papiers. Plastic Tree, South Korean Eo Il-seon's first feature depicted an unusual love triangle that was matter-of-fact and extraordinary at the same time.

The Final Night of the Hong Kong Police by Lau Shing-hon took five years to make, hence the subject may not be as alluring as it was around 1997 when the great 'take-over' was taking place. However, the film is insightful in tracing Hong Kong's recent history from the point of view of two policemen, the older one about to fly to Canada to escape the Communist rule of the island. Sonny and Wai, who are cousins, look back on the political history of Hong Kong and their place in it beginning with the anti-communist revolts in the fifties, Pekin's attempts to take over the island in 1967 and the police rebellion of the seventies to protest against the 'Independent Commission against Corruption' that was set up to put an end to corruption in the police force. The footage on the 1967 riots, which was previously censored is rather revealing.

In the International Discoveries section, Khorma, the Child of the Cemetery by Jilani Saadi from Tunisia focused on an unusual young man, an orphan with light skin and red curly hair who worked as an assistant to an old man who told stories at weddings and burials. Considered by the village as a dimwit, Khorma does not miss the opportunity to exert himself, exploiting the others as he was once exploited himself, but with dire consequences. The film alternates between slapstick comedy and serious satire dwelling on near tragedy and this does not always work to its advantage. When it comes to story-telling, the illiterate inhabitants of Jave, a small village in Brazil do a much better job in Narradores de Jave (Storytellers) by Eliane Caffe as they trust the only literate man in the village, the somewhat bohemian Antonio to record their stories. Conflicts are bound to arise but the experience itself is what counts.

The festival's guest of honour this year was Chilean born exile, Raoul Ruiz who has made films with very important and well-known actors, but always stayed committed to the true nature of his art, independent to the core. Three Sad Tigers, which won the Golden Leopard in Locarno in 1969 opened the homage that also included Le temps retrouvé (Time Regained, 1998), considered the best adaptation of Marcel Proust's novel of the same title.

In the section, Fresh breeze - New Films from Germany, When the Right One Comes Along by Stefan Hillebrand and Oliver Paulus was certainly the festival favourite. Shot inside the modern building of Collini Centre in Mannheim where the festival offices are located, the film told the fantasy filled voyage of a German cleaning lady who follows her heart all the way to a southern town in Istanbul to search for Mustafa, the temporary guard in the building who is shipped back to the old country by his parents to straighten out his bad ways. The film is very light and lighthearted. All characters except the leading lady are amateurs, either from the Turkish community of Mannheim or from the town of Adana in Turkey.

An important part of the festival is the Mannheim Meetings, which bring together producers, distributors and buyers from more than 30 countries to discuss new projects or make a sale or two. The festival is small by general standards but in some ways, this is a plus as more opportunities exist for interaction than in mega festivals such as Berlin, Venice or Cannes. 


\section{References}

\section{AWARDS:}

Main Award 2003 Mannheim-Heidelberg: Plastic Tree by Eo Il-seon (South Korea)

Rainer Werner Fassbinder Prize of Mannheim-Heidelberg: Sabado (Saturday) by Matias Bize (Chile)

Special Award of the Jury: Miffo by Daniel Lind Lagerlöf (Sweden)

Audience award: Donau, Dunaj, Duna, Dunav, Dunarea by Goran Rebic (Austria)

Prize of FIPRESCI jury: De Arm van Jezus (The Arm of Jesus) by Andre van der Hout (Holland)

Ecumenical Jury: Khamoushiye Darya (The Silence of the Sea) by Vahid Mousaian (Iran).

\section{Author Information}

Gönül DÖNMEZ-COLIN is an independent researcher and writer whose publications include Women, Islam and Cinema, Cinemas of the Other: A personal Journey with Filmmakers from the Middle East and Central Asia, Cinema of North Africa and the Middle East (ed.); Turkish Cinema: Identity, Distance and Belonging (Reaktion Books), and Routledge Dictionary of Turkish Cinema (2014). 